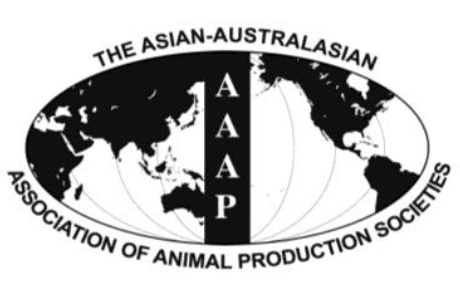

Open Access

Asian Australas. J. Anim. Sci.

Vol. 28, No. 8 : 1140-1149 August 2015

http://dx.doi.org/10.5713/ajas.14.0403

www.ajas.info

pISSN 1011-2367 elSSN 1976-5517

\title{
Effect of Age on Energy Requirement for Maintenance and Growth of Dorper and Hu Crossbred F1 Ewes Weighing 20 to 50 kg
}

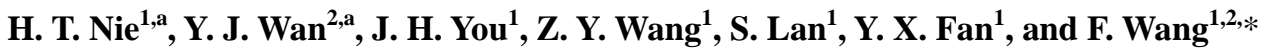 \\ ${ }^{1}$ Jiangsu Engineering Technology Research Center of Meat Sheep and Goat Industry, College of Animal Science, \\ Nanjing Agricultural University, Nanjing 210095, China
}

\begin{abstract}
This research aimed to define the energy requirement of Dorper and Hu Hybrid $\mathrm{F}_{1}$ ewes 20 to $50 \mathrm{~kg}$ of body weight, furthermore to study energy requirement changes with age and evaluate the effect of age on energy requirement parameters. In comparative slaughter trial, thirty animals were divided into three dry matter intake treatments (ad libitum, $\mathrm{n}=18 ;$ low restricted, $\mathrm{n}=6$; high restricted, $n=6$ ), and were all slaughtered as baseline, intermediate, and final slaughter groups, to calculate body chemical components and energy retained. In digestibility trial, twelve ewes were housed in individual metabolic cages and randomly assigned to three feeding treatments in accordance with the design of a comparative slaughter trial, to evaluate dietary energetic values at different feed intake levels. The combined data indicated that, with increasing age, the net energy requirement for maintenance $\left(\mathrm{NE}_{\mathrm{m}}\right) \mathrm{decreased}$ from $260.62 \pm 13.21$ to $250.61 \pm 11.79 \mathrm{~kJ} / \mathrm{kg}^{0.75}$ of shrunk body weight (SBW)/d, and metabolizable energy requirement for maintenance $\left(\mathrm{ME}_{\mathrm{m}}\right)$ decreased from $401.99 \pm 20.31$ to $371.23 \pm 17.47 \mathrm{~kJ} / \mathrm{kg}^{0.75}$ of SBW/d. Partial efficiency of ME utilization for maintenance $\left(\mathrm{k}_{\mathrm{m}}, 0.65\right.$ vs 0.68$)$ and growth $\left(\mathrm{k}_{\mathrm{g}}, 0.42\right.$ vs 0.41$)$ did not differ ( $\left.>>0.05\right)$ due to age; At the similar condition of average daily gain, net energy requirements for growth $\left(\mathrm{NE}_{\mathrm{g}}\right)$ and metabolizable energy requirements for growth $\left(\mathrm{ME}_{\mathrm{g}}\right)$ for ewes during late fattening period were $23 \%$ and $25 \%$ greater than corresponding values of ewes during early fattening period. In conclusion, the effect of age upon energy requirement parameters in the present study were similar in tendency with previous recommendations, values of energy requirement for growth $\left(\mathrm{NE}_{\mathrm{g}}\right.$ and $\mathrm{ME}_{\mathrm{g}}$ ) for Dorper and $\mathrm{Hu}$ crossbred female lambs ranged between the NRC (2007) recommendation for early and later maturating growing sheep. (Key Words: Comparative Slaughter, Net Energy Requirement, Metabolizable Energy Requirement, Fattening Period, Age, Ewe)
\end{abstract}

\section{INTRODUCTION}

Nutritional management would usually be expected to start with the knowledge of nutrient requirement, therefore, an understanding of the nutrient requirement of various sheep breeds is essential for the nutritional management. Some nutritional systems, such as National Research Councils (NRC), Agricultural Research Councils (ARC) and Commonwealth Scientific and Industrial Research Organization (CSIRO) have reported studies on nutrient

\footnotetext{
* Corresponding Author: F. Wang. Tel: +86-25-84395381, Fax: +86-25-84395314, E-mail: caeet@njau.edu.cn

${ }^{2}$ Research center of Haimen Goats, College of Animal Science, Nanjing Agricultural University, Haimen, Jiangsu 226110, China.

${ }^{a}$ These two authors contribute equally to this work.

Submitted May 28, 2014; Revised Aug. 16, 2014; Accepted Aug. 31, 2014
}

requirements and dietary utilization, in order to give recommendations for different breeds under different management conditions and diverse production of meat, milk, fiber. But the difference in nutrient requirements are widely varying even among species. Moreover, nutrient requirements are not static, they vary with genetic selection and crossbreeding.

Direct application of nutrient requirement recommendations derived from previous reports on other sheep breeds may result in an excess or deficiency in nutrients. So far, there is no report on the nutrient requirements for Dorper and $\mathrm{Hu}$ hybrid $\mathrm{F}_{1}$ sheep, which are characterized by their high fecundity and rapid growth. The objective of this study was to determined energy requirements for maintenance and growth of these crossbred growing ewes using a comparative slaughter 
technique. Furthermore, we determined energy requirement parameters of this breed ewes during early and late fattening period, to determine how energy requirements change with age and to evaluate the effect of age on energy requirement parameters.

\section{MATERIALS AND METHODS}

This study was conducted at the Research and Development Center of Haimen Goats (Haimen, JiangSu, China). Exp. 1 was conducted from December 2011 to March 2012; and Exp. 2 was conducted from June to September 2012. Humane animal care and handling procedures were followed throughout the entire experiment in accordance with procedures approved by the Guide for the Care and Use of Laboratory Animals prepared by the Ethics Committee of Nanjing Agricultural University.

\section{Experiment design and animal management}

The entire experiment consisted of two sub experiments. The schematic representation of the experimental design is shown in Figure 1.

In Exp. 1, forty-two ewes were offered the experiment diet (Table 1) for ad libitum consumption for $10 \mathrm{~d}$ until the beginning of the experiment (age of 8 weeks; $20.05 \pm 1.43$ $\mathrm{kg}$ of body weight $[\mathrm{BW}])$. During these days, all of them were treated with avermectin (Qiankun Animal Pharmaceutical Co., Ltd, Chengdu, Sichuan, China) for parasites and housed in individual stalls (approximately $1.5 \times 4 \mathrm{~m})$. Thirty of them were then randomly selected and used in the comparative slaughter trial, the remaining twelve animals were used in the digestibility trial.

In the comparative slaughter trial, six ewes were randomly selected to slaughtered as baseline group (0th day of the experiment), the remaining twenty-four ewes were randomly assigned to three nutrition treatments based on levels of dry matter intake (DMI), which were ad libitum group ( $\mathrm{AL}, \mathrm{n}=12$ ), low restricted group ( $\mathrm{LR}$, restricted to $65 \%$ of ad libitum, $\mathrm{n}=6$ ) and high restricted group (HR, restricted to $50 \%$ of ad libitum intake, $\mathrm{n}=6$ ). The selected level of the DMI was intended to make the average daily gain (ADG) of ewes under each nutrition treatment to be approximately 250, 100, and $0 \mathrm{~g} / \mathrm{d}$, respectively. Intermediate slaughter $(n=6)$ was undertaken when the average BW of animals in AL group reached $28 \mathrm{~kg}$. The remaining eighteen ewes in the three nutrition treatment groups (six ewes each group), were slaughtered when the ewes in AL group reached 35kg of BW. The amount of feed offered to the ewes in AL group was adjusted in the morning (08:00 h daily) to a 10\% refusal based on the DMI from previous day, ensuring that all animals in AL group had constant and unrestricted access to feed, water was also

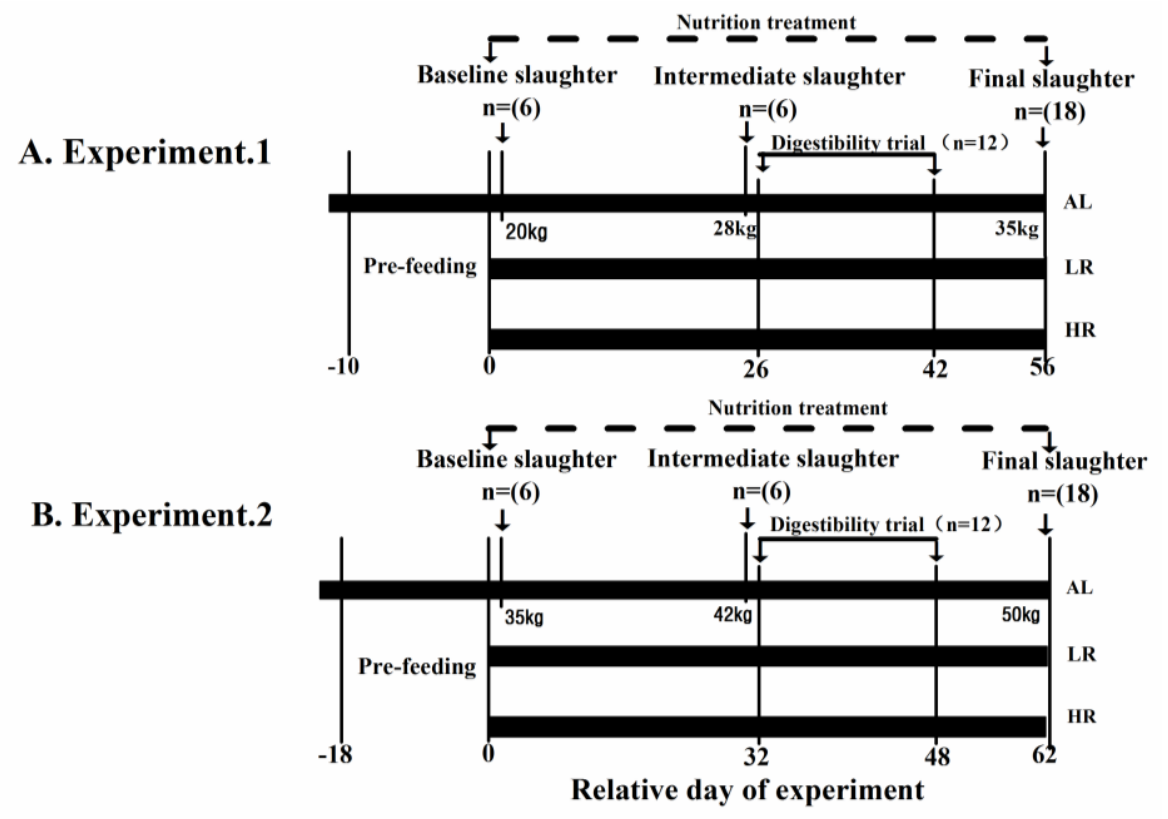

Figure 1. Schematic representation of the experimental design. (A) In experiment 1, the baseline, intermediate and final slaughter were launched at the 0,26, and 56 day of the experiment 1, when average body weight of ewes in ad libitum group reached 20, 28, and $35 \mathrm{~kg}$, respectively. For the ewes used in digestibility trial, when the average body weight of ad libitum group ewes reached $28 \mathrm{~kg}$, all of them were housed in individual metabolic cages and assigned to one of three nutrition treatment groups as above described in the comparative slaughter experiment. (B) In experiment 2, the baseline, intermediate and final slaughter were launched at the 0, 32, and 62 day of the experiment 2, when average body weight of ewes in ad libitum group reached 35, 42, and $50 \mathrm{~kg}$, respectively. When the average body weight of ad libitum group reached $42 \mathrm{~kg}$, all the ewes used in digestibility trial were housed in individual metabolic cages and assigned to nutrition treatment groups as described above in the comparative slaughter trial. 
Table 1. Basal diets and nutrient levels of ration

\begin{tabular}{lcc}
\hline Items & $\begin{array}{c}\text { Early fattening } \\
\text { period }\end{array}$ & $\begin{array}{c}\text { Later fattening } \\
\text { period }\end{array}$ \\
\hline Ingredients composition (g/100 g of DM) & \\
Corn & 41.44 & 42.83 \\
Soybean meal & 19.33 & 16.04 \\
Soy straw & 38.11 & 40.02 \\
Anhydrous calcium phosphate & 0.38 & 0.4 \\
Limestone & 0.23 & 0.2 \\
Sodium chloride & 0.4 & 0.4 \\
Premix ${ }^{1}$ & 0.11 & 0.11 \\
Total & 100 & 100 \\
Nutrient levels (g/kg of DM) & & \\
Crude protein & 138.58 & 122.83 \\
NDF & 487.72 & 499.31 \\
ADF & 203.62 & 217.19 \\
Phosphorus & 3.0 & 3.2 \\
Calcium & 6.0 & 6.9 \\
\hline DM, dry matter; NDF, neutral detergent fiber; ADF, acid detergent fiber. \\
${ }^{1}$ The amount of the microelement and mineral components: Fe $56 \mathrm{mg} / \mathrm{kg}$, \\
Cu $15 \mathrm{mg} / \mathrm{kg}, \mathrm{Mn} \mathrm{30} \mathrm{mg/kg,} \mathrm{Zn} 40 \mathrm{mg} / \mathrm{kg}, \mathrm{I} 1.5 \mathrm{mg} / \mathrm{kg}, \mathrm{Se} \mathrm{mg} / \mathrm{kg}, \mathrm{Co}$ \\
mg/kgc, S 3.2 g/kg, vitamin A 2,150 IU/kg, vitamin D $170 \mathrm{IU} / \mathrm{kg}$, \\
vitamin E 13 IU/kg, super-concentrated Yuan Kangbao $2.7 \mathrm{~g} / \mathrm{kg}$, \\
monensin1.6 g/kg, sodium sulfate $10.1 \mathrm{~g} / \mathrm{kg}$.
\end{tabular}

available ad libitum. The feed and orts were taken daily and stored at $-20^{\circ} \mathrm{C}$ for further analysis. Body weights were recorded per 10 days to measure ADG.

In the digestibility trial, twelve animals were randomly assigned to 3 levels of nutrition treatment groups as described above in the comparative slaughter trial (4 ewes each nutrition treatment group). When the average body weight of AL group reached $28 \mathrm{~kg}$, all of them were housed in individual metabolic cages. The whole trial was conducted in $16 \mathrm{~d}$ periods, which consisted of $10 \mathrm{~d}$ for adaptation and $6 \mathrm{~d}$ for sample collection. The procedure for sample collection and analysis followed the method described by Deng et al. (2012). Fecal and urinary specimens were collected and weighted once a day, a $10 \%$ sample of all these was stored at $-20^{\circ} \mathrm{C}$ for further measurement.

In Exp. 2, forty-two ewes were offered the experiment diet (Table 1) for ad libitum consumption for $18 \mathrm{~d}$ until the beginning of the experiment (age of 14 to 15 weeks; $35.68 \pm 1.68 \mathrm{~kg}$ of $\mathrm{BW})$. The design of comparative slaughter and digestibility trials of Exp. 2 was in accordance with the procedure described in Exp. 1, with minor modifications. In the comparative slaughter trial, baseline, intermediate and final group slaughter occurred when the ewes feed ad libitum reached 35,42 , and $50 \mathrm{~kg} \mathrm{BW}$, at the 0th, 32nd, and 62nd day of the experiment, in addition to these, digestibility trial was started when the average BW of ewes under ad libitum treatment reached $42 \mathrm{~kg}$ from 32nd to 48th day of the whole experiment, which included 10- day adaptation period and 6-day sample collection period.

\section{Slaughter procedure}

At slaughter, animals were fasted and water deprived for 16 hours overnight, with their body weight recorded before and after fasting. The BW of lambs after $16 \mathrm{~h}$ fasting and water deprivation was recorded as shrunk body weight (SBW) immediately prior to slaughter by exsanguination. Weights of the blood, viscera, hide, wool, head, feet, carcass, and adipose tissues removed from the internal organs were recorded. The digestive tract was weighed before and after emptying and recorded as gastrointestinal tract (GIT) content, the difference between SBW and GIT was used to determine the empty body weight (EBW). Whole body components were divided into 5 subsamples, which included muscle (removed from carcass head and feet), bone (removed from carcass, head, and feet), fat (carcass fat and vesicle fat), fat-free vesicle (inter organ, digestive tract) and fur (wool and skin removed from carcass, head, and feet). All subsamples, except wool and skin, were cut into small pieces, fully ground and then sampled and stored in $-20^{\circ} \mathrm{C}$.

\section{Samples collected and chemical analysis}

The analyses for dry material (DM), ash content were in accordance with the methods described by AOAC (1990). Gross energy (GE) was measured by XRY-1C bomb calorimeter (JinPeng Instrument Co. LTD, Wenzhou, China). Total N was determined (using Kjetec 2300, Foss, German) based on the procedure introduced by AOAC (1990), corresponding to the crude protein value multiplied by the factor of 6.25. Analyses of acid detergent fiber and neutral detergent fiber were according to Van Soest et al. (1991). Calcium and phosphorus concentration were measured according to the method described previously (Ji et al., 2013). In the comparative slaughter trial, body component samples were collected to determine DM and GE after freeze drying (XianOu-12N freeze dryer, XianOu Instrument Co., Nanjing, China), following procedure described above. Feeds, orts, urinary and fecal samples collected from the digestibility study were used to analyze for GE and DM. Dietary digestibility was calculated by dividing the dietary GE by dietary digestible energy (DE), which was computed from the GE values of the feeds, feeds ort, and feces. Dietary DE was converted to metabolizable energy (ME) by computing the difference between dietary DE less output of urinary energy (determined by the calorie value measured directly) and loss of methane energy $\left(\mathrm{CH}_{4} \mathrm{E}\right.$, as estimated by Blaxter and Clapperton [1965]).

\section{Calculation of energy requirement for maintenance and growth}

Initial body energy content of each animal was 
estimated using prediction equations regressed by body energy against EBW of the lambs from baseline group. These data, along with final body energy content calculated as the sum of the caloric value of all body components collected from comparative slaughter trial, were used to calculate the retained energy (RE). Net energy requirement for maintenance $\left(\mathrm{NE}_{\mathrm{m}}\right)$, metabolizable energy requirement for maintenance $\left(\mathrm{ME}_{\mathrm{m}}\right)$, and partial efficiency of $\mathrm{ME}$ utilization for maintenance $\left(\mathrm{k}_{\mathrm{m}}\right)$ were determined according to the methods described previously (Galvani et al., 2008); Net energy requirement for growth $\left(\mathrm{NE}_{\mathrm{g}}\right)$, metabolizable energy requirement for growth $\left(\mathrm{ME}_{\mathrm{g}}\right)$ and partial efficiency of $\mathrm{ME}$ utilization for growth $\left(k_{g}\right)$ were calculated in accordance with the method described by Pires et al. (2000).

\section{Statistical analysis}

Statistical analyses were performed using SPSS statistical software program 17.0 (SPSS Inc., Chicago, IL, USA). Values were expressed as the means \pm standard deviation. Distribution of the data followed the procedure as below, briefly, using Kolmogorov-Smirnov goodness-of fit test to confirm that all the data were in a normal distribution. The data that was confirmed to be distribution normally were used in further statistical analysis. If the data were not normally distributed, further tests were carried out using equivalent nonparametric test. Differences in feed intake, growth performance, and apparent digestibility between three different nutrition treatment groups were evaluated using a one-way analysis of variance. Post hoc differences between treatment groups were further analyzed using Turkey's test. A p value of less than 0.05 was considered to be statistically significant, the outlier analysis was carried out when the data of each dependent variable was outside the range of 3 times of standard deviation, and the data of one ewe from each experiment were removed from the dataset based on these analysis. Linear regression analysis were conducted with PROM GLM. The assumptions of the models, in terms of homoscedasticity, independency, and normality of errors, were examined by plotting residuals against the predicted values.

\section{RESULTS}

\section{Experiment 1: Energy requirement of Dorper and $\mathrm{Hu}$ crossbred ewes during early fattening period}

Intake and growth performance: The intake and growth performance of ewes in the present study are illustrated in Table 2. Ewes under AL treatment had 56.10\% and $103.18 \%$ greater DMI than their counterparts in LR and HR groups, respectively $(\mathrm{p}<0.01)$. No significant difference was detected in initial BW between ewes under AL, LR and HR treatment, respectively ( $p>0.10)$. Final BW, Net gain of BW and ADG increased with increasing of nutritional intake level $(\mathrm{p}<0.01)$, and AL group ewes had greater final BW, Net gain of BW and ADG than those of ewes under either restricted feeding treatments.

Methane production and dietary metabolizable energy concentration: Results of the digestibility trial are presented in Table 3. As DMI increased, the daily intake of GE, DE, and ME increased linearly $(\mathrm{p}<0.01)$. Compared with the ewes under LR and HR nutrition treatments, ewes in $\mathrm{AL}$ group had greater daily $\mathrm{CH}_{4} \mathrm{E}$ production (2.29 vs 1.42 and $1.00 \mathrm{MJ} / \mathrm{d}$ for nutrition treatment of $\mathrm{AL}, \mathrm{LR}$, and $\mathrm{HR}$, respectively). Similar $\mathrm{CH}_{4} \mathrm{E}$ production expressed as $\mathrm{GE}$ $\left(\mathrm{CH}_{4} \mathrm{E} / \mathrm{GE}\right)$ was detected between $\mathrm{AL}, \mathrm{LR}$, and $\mathrm{HR}$ groups, but the mean values of $\mathrm{CH}_{4} \mathrm{E} / \mathrm{GE}$ under three nutrition treatment groups showed that the relative $\mathrm{CH}_{4} \mathrm{E} / \mathrm{GE}$ output tended to decrease with decreasing feed intake. The values of $\mathrm{DE} / \mathrm{GE}$ and $\mathrm{ME} / \mathrm{GE}$ of the diet were greater $(\mathrm{p}<0.05)$ with ewes fed at HR than those of ewes under AL nutrition treatment. The estimated values of metabolizable energy concentration (MEC) were 10.92, 11.67, and $12.03 \mathrm{MJ} / \mathrm{kg}$, for AL, LR, and HR group respectively.

Energy requirement for maintenance: Figure 2 A shows

Table 2. Intake and growth performance of Dorper and $\mathrm{Hu}$ crossbred ewes fed with three nutrition treaments during early and late fattening period

\begin{tabular}{|c|c|c|c|c|c|c|c|c|}
\hline \multirow{2}{*}{ Items } & \multicolumn{3}{|c|}{ Early fattening period } & \multirow{2}{*}{ p-value ${ }^{1}$} & \multicolumn{3}{|c|}{ Late fattening period } & \multirow{2}{*}{ p-value } \\
\hline & $\mathrm{AL}^{1}$ & LR & HR & & $\mathrm{AL}$ & LR & HR & \\
\hline DMI (kg/d) & $1.28 \pm 0.05^{\mathrm{a}}$ & $0.82 \pm 0.00^{\mathrm{b}}$ & $0.63 \pm 0.00^{\mathrm{c}}$ & $<0.01$ & $1.66 \pm 0.09^{\mathrm{a}}$ & $1.12 \pm 0.00^{\mathrm{b}}$ & $0.81 \pm 0.00^{\mathrm{c}}$ & $<0.01$ \\
\hline DMI $\left(\mathrm{g} / \mathrm{kg}^{0.75}\right.$ of SBW/d) & $110.09 \pm 6.78^{\mathrm{a}}$ & $83.86 \pm 4.18^{\mathrm{b}}$ & $65.60 \pm 2.12^{\mathrm{c}}$ & $<0.01$ & $103.38 \pm 6.96^{\mathrm{a}}$ & $74.82 \pm 0.89$ & $58.00 \pm 0.12$ & $<0.01$ \\
\hline $\begin{array}{l}\text { ME intake } \\
\left(\mathrm{kJ} / \mathrm{kg}^{0.75} \text { of SBW/d) }\right.\end{array}$ & $859.27 \pm 25.04^{\mathrm{a}}$ & $623.17 \pm 33.12^{b}$ & $453.44 \pm 11.52^{\mathrm{c}}$ & $<0.01$ & $847.92 \pm 71.11^{\mathrm{a}}$ & $747.49 \pm 8.96^{\mathrm{b}}$ & $608.98 \pm 7.11^{\mathrm{c}}$ & $<0.01$ \\
\hline Initial BW (kg) & $20.80 \pm 1.11$ & $18.98 \pm 1.43$ & $20.50 \pm 1.18$ & $>0.05$ & $36.30 \pm 2.22$ & $36.43 \pm 1.04$ & $34.73 \pm 0.98$ & $>0.05$ \\
\hline Final BW (kg) & $34.76 \pm 1.50^{\mathrm{a}}$ & $25.47 \pm 1.80^{\mathrm{b}}$ & $21.95 \pm 0.72^{\mathrm{c}}$ & $<0.01$ & $48.38 \pm 2.46^{\mathrm{a}}$ & $41.25 \pm 0.90^{\mathrm{b}}$ & $35.77 \pm 0.44^{\mathrm{c}}$ & $<0.01$ \\
\hline Net gain of BW (kg) & $13.96 \pm 0.93^{\mathrm{a}}$ & $6.48 \pm 1.43^{\mathrm{b}}$ & $1.45 \pm 0.77^{\mathrm{c}}$ & $<0.01$ & $12.08 \pm 0.87^{\mathrm{a}}$ & $4.83 \pm 1.51^{\mathrm{b}}$ & $1.04 \pm 0.63^{\mathrm{c}}$ & $<0.05$ \\
\hline Average daily gain (g/d) & $249.29 \pm 16.69^{\mathrm{a}}$ & $115.77 \pm 25.49^{\mathrm{b}}$ & $25.89 \pm 13.68^{c}$ & $<0.01$ & $215.77 \pm 15.54^{\mathrm{a}}$ & $86.16 \pm 26.90^{\mathrm{b}}$ & $18.62 \pm 11.24^{\mathrm{c}}$ & $<0.01$ \\
\hline
\end{tabular}

AL, ad libitum treatment; LR, low restricted treatment; HR, high restricted treatment; DMI, dry matter intake; SBW, shrunk body weight; ME, metabolizable energy; BW, body weight.

${ }^{1}$ Probability (p-value) of the linear effect of decreasing feed intake.

${ }^{a, b, c}$ Means within same rows with different superscript letters are significantly different $(\mathrm{p}<0.05)$; with the same letter mean no significantly difference $(\mathrm{p}>0.05)$. 
Table 3. Energetic content of the ration offered to Doper and $\mathrm{Hu}$ crossbred ewes under different nutrition treatment during early and late fattening period

\begin{tabular}{|c|c|c|c|c|c|c|c|c|}
\hline \multirow{2}{*}{ Items } & \multicolumn{3}{|c|}{ Early fattening period } & \multirow{2}{*}{ p-value ${ }^{1}$} & \multicolumn{3}{|c|}{ Late fattening period } & \multirow{2}{*}{$\mathrm{p}$-valu } \\
\hline & $\mathrm{AL}^{1}$ & LR & HR & & $\mathrm{AL}$ & LR & HR & \\
\hline$\overline{\mathrm{DMI}}(\mathrm{kg} / \mathrm{d})$ & $1.33 \pm 0.17^{\mathrm{a}}$ & $0.84 \pm 0.01^{\mathrm{b}}$ & $0.61 \pm 0.01^{\mathrm{c}}$ & $<0.05$ & $1.71 \pm 0.16^{\mathrm{a}}$ & $1.16 \pm 0.01^{\mathrm{b}}$ & $0.83 \pm 0.02^{\mathrm{c}}$ & $<0.05$ \\
\hline DM apparent digestibility (\%) & $66.26 \pm 1.78^{\mathrm{a}}$ & $68.17 \pm 2.13^{\mathrm{ab}}$ & $71.01 \pm 1.13^{\mathrm{b}}$ & $<0.05$ & $63.63 \pm 2.25$ & $66.37 \pm 3.08$ & $68.55 \pm 2.28$ & $<0.05$ \\
\hline GE intake $(\mathrm{MJ} / \mathrm{d})$ & $28.87 \pm 2.28^{\mathrm{a}}$ & $18.71 \pm 0.23^{\mathrm{b}}$ & $13.41 \pm 0.19^{\mathrm{c}}$ & $<0.01$ & $37.69 \pm 2.09^{\mathrm{a}}$ & $25.85 \pm 0.19^{b}$ & $18.79 \pm 0.29^{\mathrm{c}}$ & $<0.01$ \\
\hline $\mathrm{CH}_{4} \mathrm{E}(\mathrm{MJ} / \mathrm{d})$ & $2.29 \pm 0.11^{\mathrm{a}}$ & $1.42 \pm 0.09^{\mathrm{b}}$ & $1.00 \pm 0.14^{\mathrm{c}}$ & $<0.01$ & $3.17 \pm 0.21^{\mathrm{a}}$ & $1.98 \pm 0.08^{\mathrm{b}}$ & $1.38 \pm 0.08^{\mathrm{c}}$ & $<0.01$ \\
\hline $\mathrm{DE}(\mathrm{MJ} / \mathrm{d})$ & $17.80 \pm 1.87^{\mathrm{a}}$ & $11.92 \pm 1.03^{\mathrm{b}}$ & $8.83 \pm 0.65^{\mathrm{c}}$ & $<0.01$ & $22.48 \pm 2.13^{\mathrm{a}}$ & $15.67 \pm 0.89^{\mathrm{b}}$ & $11.50 \pm 1.08^{\mathrm{c}}$ & $<0.01$ \\
\hline $\mathrm{ME}(\mathrm{MJ} / \mathrm{d})$ & $14.53 \pm 1.43^{\mathrm{a}}$ & $9.80 \pm 0.89^{\mathrm{b}}$ & $7.34 \pm 0.45^{\mathrm{c}}$ & $<0.01$ & $17.99 \pm 3.09^{\mathrm{a}}$ & $12.73 \pm 1.01^{\mathrm{b}}$ & $9.55 \pm 0.77^{\mathrm{c}}$ & $<0.01$ \\
\hline $\mathrm{CH}_{4} \mathrm{E} / \mathrm{GE}(\%)$ & $7.93 \pm 0.78^{\mathrm{a}}$ & $7.61 \pm 0.33^{\mathrm{a}}$ & $7.43 \pm 0.57^{\mathrm{a}}$ & $>0.05$ & $8.41 \pm 0.94^{\mathrm{a}}$ & $7.67 \pm 0.41^{\mathrm{a}}$ & $7.34 \pm 1.26 \mathrm{~b}^{\mathrm{c}}$ & $>0.05$ \\
\hline $\mathrm{DE} / \mathrm{GE}(\%)$ & $61.72 \pm 1.76^{\mathrm{a}}$ & $63.93 \pm 1.17^{\mathrm{ab}}$ & $65.65 \pm 1.21^{\mathrm{b}}$ & $<0.05$ & $59.70 \pm 1.33^{\mathrm{a}}$ & $60.74 \pm 1.67^{\mathrm{a}}$ & $61.20 \pm 1.31^{\mathrm{b}}$ & $<0.10$ \\
\hline ME/GE (\%) & $50.29 \pm 0.78^{\mathrm{a}}$ & $52.52 \pm 1.13^{\mathrm{ab}}$ & $54.57 \pm 0.88^{\mathrm{b}}$ & $<0.05$ & $47.73 \pm 0.64^{\mathrm{a}}$ & $49.34 \pm 0.98^{\mathrm{a}}$ & $50.82 \pm 1.09^{b}$ & $<0.05$ \\
\hline ME/DE (\%) & $81.48 \pm 1.98^{\mathrm{a}}$ & $82.15 \pm 2.09^{\mathrm{a}}$ & $83.13 \pm 1.17^{\mathrm{a}}$ & $>0.05$ & $79.96 \pm 1.76^{\mathrm{a}}$ & $81.24 \pm 1.46^{\mathrm{a}}$ & $83.04 \pm 1.99^{\mathrm{a}}$ & $>0.05$ \\
\hline $\operatorname{MEC}(\mathrm{MJ} / \mathrm{kg})$ & $10.92 \pm 0.26^{\mathrm{a}}$ & $11.67 \pm 0.33^{\mathrm{b}}$ & $12.03 \pm 0.17^{\mathrm{bc}}$ & $<0.05$ & $10.52 \pm 0.26^{\mathrm{a}}$ & $10.97 \pm 0.35^{\mathrm{b}}$ & $11.51 \pm 0.26^{\mathrm{bc}}$ & $<0.05$ \\
\hline
\end{tabular}

AL, ad libitum treatment; LR, low restricted treatment; HR, high restricted treatment; DMI, dry matter intake; DM, dry matter; GE, gross energy; DE, digestible energy; $\mathrm{ME}$, metabolizable energy; $\mathrm{CH}_{4} \mathrm{E}$, methane energy; $\mathrm{MEC}$, metabolizable energy concentration.

${ }^{1}$ Probability (p-value) of the linear effect of decreasing feed intake.

${ }^{a, b, c}$ Means within same rows with different superscript letters are significantly different $(\mathrm{p}<0.05)$; with the same letter mean no significantly difference $(\mathrm{p}>0.05)$.

that the linear regression equation between heat production (HP) and metabolizable energy intake (MEI) was $\log _{10}(\mathrm{HP}$, $\mathrm{kJ} / \mathrm{kg}^{0.75}$ of SBW/d $)=2.416( \pm 0.0192)+0.00046( \pm 0.0000) \times$ MEI $\left(\mathrm{kJ} / \mathrm{kg}^{0.75}\right.$ of SBW/d) $\left(\mathrm{r}^{2}=0.92 ; \mathrm{n}=23, \mathrm{p}<0.001\right)$. In accordance with the procedure described in Materials and Methods, the antilog of the intercept of the linear regression indicated that the $\mathrm{NE}_{\mathrm{m}}$ was $260.62 \pm 13.21 \mathrm{~kJ} / \mathrm{kg}^{0.75}$ of $\mathrm{SBW} / \mathrm{d}$, and it corresponds to the $\mathrm{ME}_{\mathrm{m}}$ of $401.99 \pm 20.31$ $\mathrm{kJ} / \mathrm{kg}^{0.75}$ of SBW/d, calculated by iteration of the equation regressed by $\log _{10} \mathrm{HP}$ against MEI. The $k_{m}$ value, represented by $\mathrm{NE}_{\mathrm{m}} / \mathrm{ME}_{\mathrm{m}}$, was calculated as value of 0.65 .

Energy requirement for growth: The regression relationship estimating body composition (i.e., body water, fat, and protein) of the ewes from 20 to $35 \mathrm{~kg}$ of $\mathrm{BW}$ is presented in Table 4. Absolute estimated values of body components at different SBW are illustrated in Table 5, indicating that proportion of body fat increased, whereas whole body protein and whole body water proportion
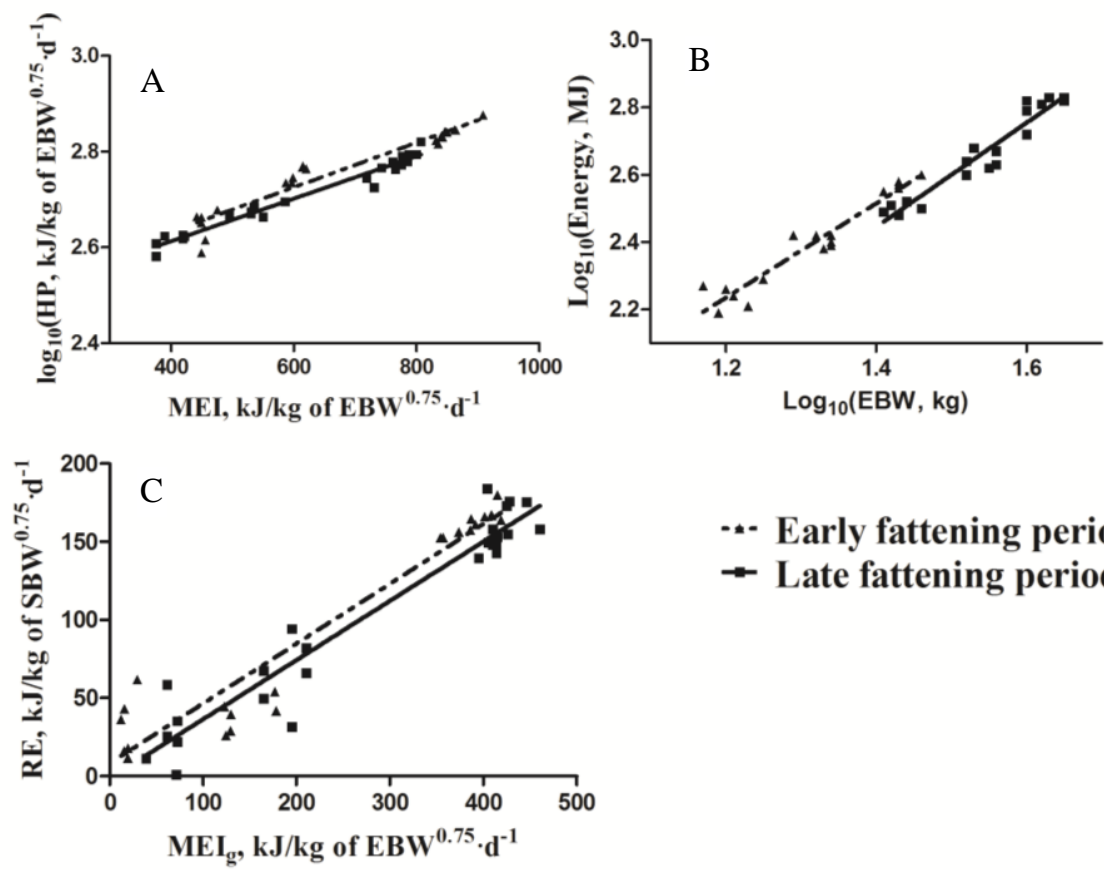

-.- Early fattening period
$\rightarrow$ Late fattening period

Figure 2. Energy requirement of Dorper and Hu crossbred ewes. (A) Requirement of net requirement for maintenance. (B) Requirement of metabolizable energy for growth. (C) Partial efficiency of metabolizable energy utilization for growth. Triangles and dotted lines indicate the corresponding parameters for ewes during early fattening period when the body weight ranged from 20 to $35 \mathrm{~kg}$; the parameters of ewes in late fattening period when the body weight ranged from 35 to $50 \mathrm{~kg}$ are represented by squares and solid lines. 
Table 4. Regression equations developed to estimate final body chemical components and energy content vale of Dorper and Hu crossbred ewes during early and late fattening period

\begin{tabular}{|c|c|c|c|c|}
\hline $\mathrm{BW}(\mathrm{kg})$ & Regression equations & $\mathrm{n}$ & $r^{2}$ & p-value \\
\hline \multirow[t]{4}{*}{20 to 35} & $\log ($ Water, $g)=2.957( \pm 0.208)+0.846( \pm 0.057) \times \log _{10}(E B W, \mathrm{~kg})$ & 17 & 0.93 & $<0.001$ \\
\hline & $\log _{10}($ Protein, $g)=2.700( \pm 0.053)+0.700( \pm 0.041) \times \log _{10}(E B W, k g)$ & 17 & 0.97 & $<0.001$ \\
\hline & $\log _{10}($ Fat, g $)=1.412( \pm 0.277)+1.562( \pm 0.211) \times \log _{10}(E B W, k g)$ & 17 & 0.90 & $<0.001$ \\
\hline & $\log _{10}($ Energy, MJ $)=0.618( \pm 0.143)+1.337( \pm 0.088) \times \log _{10}($ EBW, $\mathrm{kg})$ & 17 & 0.92 & $<0.001$ \\
\hline \multirow[t]{4}{*}{35 to 50} & $\log ($ Water, $g)=2.976( \pm 0.141)+0.826( \pm 0.067) \times \log _{10}(E B W, k g)$ & 18 & 0.96 & $<0.001$ \\
\hline & $\log _{10}($ Protein, $g)=2.641( \pm 0.113)+0.742( \pm 0.093) \times \log _{10}(\mathrm{EBW}, \mathrm{kg})$ & 18 & 0.94 & $<0.001$ \\
\hline & $\log _{10}($ Fat, g $)=1.019( \pm 0.189)+1.838( \pm 0.122) \times \log _{10}(E B W, k g)$ & 18 & 0.93 & $<0.001$ \\
\hline & $\log _{10}($ Energy, MJ $)=0.252( \pm 0.130)+1.545( \pm 0.084) \times \log _{10}(E B W, k g)$ & 18 & 0.96 & $<0.001$ \\
\hline
\end{tabular}

BW, body weight; EBW, shrunk body weight.

Table 5. Body chemical components proportion of Dorper and Hu crossbred ewes during early and late fattening periods

\begin{tabular}{|c|c|c|c|c|c|c|c|c|}
\hline \multirow{2}{*}{$\begin{array}{l}\text { Items } \\
\text { SBW (kg) }\end{array}$} & \multicolumn{4}{|c|}{ Early fattening period } & \multicolumn{4}{|c|}{ Late fattening period } \\
\hline & 20 & 25 & 30 & 35 & 35 & 40 & 45 & 50 \\
\hline EBW (kg) & 17.05 & 21.32 & 25.58 & 29.84 & 29.58 & 33.96 & 38.33 & 42.71 \\
\hline \multicolumn{9}{|c|}{ Body chemical components proportion ${ }^{1}$} \\
\hline Water $(\mathrm{g} / \mathrm{kg}$ of EBW) & 585.62 & 565.14 & 549.05 & 535.85 & 524.86 & 512.41 & 501.72 & 492.37 \\
\hline Protein $(\mathrm{g} / \mathrm{kg}$ of EBW) & 214.68 & 200.25 & 189.26 & 180.47 & 182.59 & 176.21 & 170.78 & 166.09 \\
\hline Fat $(\mathrm{g} / \mathrm{kg}$ of $\mathrm{EBW})$ & 125.74 & 143.19 & 159.11 & 173.87 & 178.53 & 200.41 & 221.83 & 242.86 \\
\hline
\end{tabular}

SBW, shrunk body weight; EBW, empty body weight.

${ }^{1}$ Values were calculated as body chemical components weight/EBW.

decreased as SBW ranged from 20 to $35 \mathrm{~kg}$. Results of our study suggest that $\mathrm{NE}_{\mathrm{g}}$ values of ewes with $\mathrm{BW}$ ranging from 20 to $35 \mathrm{~kg}$ at $\mathrm{ADG}$ of 0 to $300 \mathrm{~g}$ scaled from 1.25 to $4.55 \mathrm{MJ} / \mathrm{d}$ (Table 6), which were obtained from regression equations between EBW and body energy content: $\log _{10}$ $($ Final body energy, MJ) $=0.618( \pm 0.143)+1.337( \pm 0.088) \times$ $\log _{10}(\mathrm{EBW}, \mathrm{kg}),\left(\mathrm{r}^{2}=0.92 ; \mathrm{n}=17, \mathrm{p}<0.001\right)$. Value of $k_{g}$, was 0.42 , calculated as the slope of the regression between $\mathrm{RE}$ and metabolizable energy intake for growth $\left(\mathrm{MEI}_{\mathrm{g}}\right.$, Figure 1C): RE $\left(\mathrm{kJ}^{\mathrm{kg}} \mathrm{kg}^{0.75}\right.$ of $\left.\mathrm{SBW} / \mathrm{d}\right)=5.552$ $( \pm 6.873)+0.4221( \pm 0.0286) \times \mathrm{MEI}_{\mathrm{g}}\left(\mathrm{kJ} / \mathrm{kg}^{0.75}\right.$ of $\left.\mathrm{SBW} / \mathrm{d}\right),\left(\mathrm{r}^{2}\right.$ $=0.93 ; \mathrm{n}=23, \mathrm{p}<0.001)$. The metabolizable energy requirements for growth $\left(\mathrm{ME}_{\mathrm{g}}\right)$ values of ewes from 20 to $35 \mathrm{~kg}$ of $\mathrm{BW}$ with $\mathrm{ADG}$ ranging from 0 to $300 \mathrm{~g}$ were scaled from 2.98 to $10.83 \mathrm{MJ} / \mathrm{d}$ (Table 7).

Experiment 2: Energy requirement of Doper and Hu

Table 6. Requirement of $\mathrm{NE}_{\mathrm{g}}(\mathrm{MJ} / \mathrm{d})$ for Dorper and $\mathrm{Hu}$ crossbred ewes

\begin{tabular}{ccccccccc}
\hline $\begin{array}{c}\text { ADG } \\
(\mathrm{g} / \mathrm{d})\end{array}$ & \multicolumn{7}{c}{ SBW $(\mathrm{kg})$} \\
\cline { 2 - 8 } & 20 & 25 & 30 & 35 & 35 & 40 & 45 & 50 \\
\hline 100 & 1.25 & 1.35 & 1.44 & 1.51 & 1.53 & 1.64 & 1.75 & 1.86 \\
150 & 1.87 & 2.02 & 2.16 & 2.27 & 2.30 & 2.47 & 2.63 & 2.78 \\
200 & 2.50 & 2.70 & 2.87 & 3.03 & 3.06 & 3.29 & 3.51 & 3.71 \\
250 & 3.12 & 3.37 & 3.59 & 3.79 & 3.83 & 4.11 & 4.38 & 4.64 \\
300 & 3.75 & 4.05 & 4.31 & 4.55 & 4.60 & 4.94 & 5.26 & 5.57 \\
\hline
\end{tabular}

$\mathrm{NEg}$, net energy requirements for growth; ADG, average daily gain; SBW, shrunk body weight.

\section{crossbred ewes during late fattening period}

Intake and growth performance: As shown in Table 2. AL group ewes consumed $1.28 \mathrm{~kg} / \mathrm{d}$ during the early fattening period and $1.66 \mathrm{~kg} / \mathrm{d}$ during the late fattening period and had a greater DMI than their counterparts in LR and HR groups, respectively $(\mathrm{p}<0.01)$. Final $\mathrm{BW}$, Net gain of $\mathrm{BW}$ and $\mathrm{ADG}$ increased with increasing nutritional intake level $(\mathrm{p}<0.01)$. Difference in initial BW between ewes under AL, LR, and HR treatment was not detected $(\mathrm{p}>0.10)$.

Methane production and dietary metabolizable energy concentration: Results of the digestibility trial for the ewes with BW ranging from 35 to $50 \mathrm{~kg}$ are shown in Table 3 . As DMI increased, daily intake of GE, DE, and ME increased $(\mathrm{p}<0.01)$. Compared with those ewes under LR and HR nutrition treatment, ewes fed ad libitum had greater daily $\mathrm{CH}_{4} \mathrm{E}$ production (3.17 vs 1.98 and $1.38 \mathrm{MJ} / \mathrm{d}$ for ewes

Table 7. Requirement of $\mathrm{ME}_{\mathrm{g}}(\mathrm{MJ} / \mathrm{d})$ for Dorper and $\mathrm{Hu}$ crossbred ewes

\begin{tabular}{ccccccccc}
\hline $\begin{array}{c}\text { ADG } \\
(\mathrm{g} / \mathrm{d})\end{array}$ & 20 & 25 & 30 & 35 & 35 & 40 & 45 & 50 \\
\hline 100 & 2.98 & 3.21 & 3.43 & 3.60 & 3.73 & 4.01 & 4.27 & 4.52 \\
150 & 4.45 & 4.81 & 5.14 & 5.40 & 5.60 & 6.01 & 6.41 & 6.79 \\
200 & 5.95 & 6.43 & 6.83 & 7.21 & 7.47 & 8.02 & 8.55 & 9.05 \\
250 & 7.43 & 8.02 & 8.55 & 9.02 & 9.35 & 10.03 & 10.69 & 11.32 \\
300 & 8.93 & 9.64 & 10.26 & 10.83 & 11.22 & 12.04 & 12.83 & 13.59 \\
\hline
\end{tabular}

MEg, metabolizable energy requirements for growth; ADG, average daily gain; SBW, shrunk body weight. 
under AL, LR, and HR, respectively). Similar relative $\mathrm{CH}_{4} \mathrm{E}$ loss expressed as $\mathrm{GE}\left(\mathrm{CH}_{4} \mathrm{E} / \mathrm{GE}\right)$ was detected between $\mathrm{AL}$, $\mathrm{LR}$, and HR groups, but the mean values of $\mathrm{CH}_{4} \mathrm{E} / \mathrm{GE}$ under three nutrition treatment groups showed that the $\mathrm{CH}_{4} \mathrm{E} / \mathrm{GE}$ tended to decrease linearly with decreasing feed intake. Relative intake of DE and ME expressed as GE, DE/GE, and ME/GE, was greater $(p<0.05)$ with the ewes in HR group than that of ewes under AL nutrition treatment. The estimated mean values of MEC were 10.52, 11.37, and $11.51 \mathrm{MJ} / \mathrm{kg}$, for $\mathrm{AL}, \mathrm{LR}$, and HR groups respectively.

Energy requirement for maintenance: Figure 2A shows that the linear regression equation between $\mathrm{HP}$ and MEI was $\log _{10}\left(\mathrm{HP}, \mathrm{kJ} / \mathrm{kg}^{0.75}\right.$ of $\left.\mathrm{SBW}\right)=2.399( \pm 0.0208)+$ $0.00044( \pm 0.0000) \times \mathrm{MEI}, \mathrm{kJ} / \mathrm{kg}^{0.75}$ of SBW/d $\left(\mathrm{r}^{2}=0.97 ; \mathrm{n}=\right.$ $25, \mathrm{p}<0.001)$. The antilog of the intercept of the linear regression indicated that the $\mathrm{NE}_{\mathrm{m}}$ was $250.61 \pm 11.79$ $\mathrm{kJ} / \mathrm{kg}^{0.75}$ of SBW/d. The $\mathrm{ME}_{\mathrm{m}}$ was $371.23 \pm 17.47 \mathrm{~kJ} / \mathrm{kg}^{0.75}$ of SBW/d, calculated by iteration of the equation regressed by $\log _{10} \mathrm{HP}$ against MEI. The $\mathrm{k}_{\mathrm{m}}$ value, represented by $\mathrm{NE}_{\mathrm{m}} / \mathrm{ME}_{\mathrm{m}}$, was 0.68 .

Energy requirement for growth: The regression relationship to estimate body composition (i.e., body water, fat, protein and energy retained values) of the ewes from 35 to $50 \mathrm{~kg}$ of $\mathrm{BW}$ is presented in Table 4. Absolute estimated values of body components at different SBW are shown in Table 5, as SBW ranged from 35 to $50 \mathrm{~kg}$, the proportion of body fat and body energy increased, whereas body protein and body water proportion decreased. Results of our study suggested that $\mathrm{NE}_{\mathrm{g}}$ value of ewes at 35 to $50 \mathrm{~kg}$ of BW at ADG of 0 to $300 \mathrm{~g}$ ranged from 1.53 to $5.57 \mathrm{MJ} / \mathrm{d}$ (Table 6), which was obtained from equations regression between EBW and body energy content: $\log _{10}$ (Final body energy, $\mathrm{MJ})=0.252( \pm 0.130)+1.545( \pm 0.084) \times \log _{10}(\mathrm{EBW}, \mathrm{kg}),\left(\mathrm{r}^{2}\right.$ $=0.92 ; \mathrm{n}=17, \mathrm{p}<0.001)$. The value of $k_{g}$ was 0.41 , calculated as the slope of the regression between RE and $\mathrm{MEI}_{\mathrm{g}}$ (Figure 2C): RE $\left(\mathrm{kJ} / \mathrm{kg}^{0.75}\right.$ of $\left.\mathrm{SBW} / \mathrm{d}\right)=-8.772$ $( \pm 6.97)+0.4125( \pm 0.0170) \times \mathrm{MEI}_{\mathrm{g}}\left(\mathrm{kJ} / \mathrm{kg}^{0.75}\right.$ of $\left.\mathrm{SBW} / \mathrm{d}\right),\left(\mathrm{r}^{2}=\right.$ $0.95 ; \mathrm{n}=24, \mathrm{p}<0.001)$. The $\mathrm{ME}_{\mathrm{g}}$ value of ewes at $\mathrm{ADG}$ ranging from 0 to $300 \mathrm{~g}$ were scaled from 3.73 to 13.59 $\mathrm{MJ} / \mathrm{d}$ (Table 7).

\section{Divergence of nutrient requirement between ewes during different fattening periods}

The combined data in the present study indicated that $\mathrm{NE}_{\mathrm{m}}, \mathrm{ME}_{\mathrm{m}}, \mathrm{k}_{\mathrm{m}}$, and $k_{g}$ did not differ ( $\mathrm{p}>0.10$ ) due to age; although not statistically different, as age increased, $\mathrm{NE}_{\mathrm{m}}$ decreased from $260.62 \pm 13.21$ to $250.61 \pm 11.79 \mathrm{~kJ} / \mathrm{kg}^{0.75}$ of $\mathrm{SBW} / \mathrm{d}$, and $\mathrm{ME}_{\mathrm{m}}$ decreased from 400.61 \pm 20.31 to $371.23 \pm 17.47 \mathrm{~kJ} / \mathrm{kg}^{0.75}$ of SBW/d. Additionally, in our study, $\mathrm{k}_{\mathrm{m}}$ value calculated from the ewes from 20 to $35 \mathrm{~kg}$ of BW was 0.65 , which was $4 \%$ less than the value (0.68) of ewes with $\mathrm{BW}$ ranging from 35 to $50 \mathrm{~kg}$. Results of $\mathrm{ME}_{\mathrm{g}}$ and $\mathrm{NE}_{\mathrm{g}}$ values for lambs with various ADG of SBW are presented in Table 6 and 7, indicating that $\mathrm{NE}_{\mathrm{g}}$ was significantly different $(p>0.10)$ between ewes with different ages, and was $23 \%$ greater for ewes with BW ranging from 35 to 50 $\mathrm{kg}$ of SBW during late fattening period than for ewes from 20 to $35 \mathrm{~kg}$ of SBW during early fattening period. Value of $k_{g}$ obtained for ewes during the early fattening period was slightly greater than that for ewes during late fattening period (0.42 vs 0.41). The $\mathrm{ME}_{\mathrm{g}}$ of ewes during early fattening period at $\mathrm{ADG}$ range from 0 to $300 \mathrm{~g}$ were approximately $25 \%$ greater than those values determined for ewes during late fattening period at ADG range from 0 to $300 \mathrm{~g}$. Our combined data indicated that the $\mathrm{NE}_{\mathrm{g}}$ and $\mathrm{ME}_{\mathrm{g}}$ increased as age increased at a same BW gain level.

\section{DISCUSSION}

The $\mathrm{NE}_{\mathrm{m}}$ value of Dorper and $\mathrm{Hu}$ crossbred ewes during early and late fattening periods determined in present study was 260.62 and $250.61 \mathrm{~kJ} / \mathrm{kg}^{0.75}$ of SBW/d, which was on average $255.62 \mathrm{~kJ} / \mathrm{kg}^{0.75}$ of SBW/d. This average value was $9 \%$ greater than the value reported by (NRC, 2007; 234.3 $\mathrm{kJ} / \mathrm{kg}^{0.75}$ of $\left.\mathrm{SBW} / \mathrm{d}\right)$, and was close to the value $(259.4$ $\mathrm{kJ} / \mathrm{kg}^{0.75}$ of SBW/d) recommended by CSIRO (2007). When expressed as per unit of $\mathrm{BW}$, values of $\mathrm{NE}_{\mathrm{m}}$ for early $\left(248.44 \mathrm{~kJ} / \mathrm{kg}^{0.75}\right.$ of $\left.\mathrm{BW} / \mathrm{d}\right)$ and late $\left(238.08 \mathrm{~kJ} / \mathrm{kg}^{0.75}\right.$ of $\mathrm{BW} / \mathrm{d})$ fattening periods, were both lower than the value (312 $\mathrm{kJ} / \mathrm{kg}^{0.75}$ of BW/d) obtained from a comparative slaughter trial with tropic lambs (Silva et al., 2003). As Table 8 shown, proportions of GIT, liver, heart, lung, spleen, kidney proportion of animals in ad libitum group decreased with age increased, which need a higher energy requirement, consequently, represented a greater NEm of ewes during early fattening period. As recommended by (CSIRO) 2007 and NRC (2007), the adjustment for the effect of age on energy requirements for fasting metabolism was: $\operatorname{Exp}(-0.03 \times y e a r s$ of age), with years of age greater than 6 set equal to 6 . Based on this equation, value of $\mathrm{NE}_{\mathrm{m}}$ SBW for ewes during early fattening period (average age was 4 months) was $1.28 \mathrm{~kJ}$ per unit of $\mathrm{SBW}^{0.75} / \mathrm{d}$ greater than

Table 8. Values of energy requirement for maintenance, internal organs proportion of Dorper and Hu crossbred ewes at different BW

\begin{tabular}{|c|c|c|c|c|c|c|c|c|}
\hline \multirow{2}{*}{ BW } & \multicolumn{2}{|c|}{ Energy requirement $\left(\mathrm{kJ} \mathrm{kg}^{-0.75}\right.$ of $\left.\mathrm{SBW} / \mathrm{d}\right)$} & \multicolumn{6}{|c|}{ Proportion of internal organ $(\mathrm{g} / 100 \mathrm{~g} \text { of } \mathrm{EBW})^{1}$} \\
\hline & $\mathrm{NE}_{\mathrm{m}}$ & $\mathrm{ME}_{\mathrm{m}}$ & GIT & Liver & Heart & Spleen & Lung & Kidney \\
\hline 20 to 35 & $260.62(13.21)$ & $400.61(20.31)$ & 8.98 & 2.36 & 0.75 & 0.24 & 1.44 & 0.33 \\
\hline 35 to 50 & 250.61(11.79) & 371.23(17.47) & 6.42 & 2.04 & 0.47 & 0.13 & 0.81 & 0.27 \\
\hline
\end{tabular}

BW, body weight; SBW, shrunk body weight; GIT, gastrointestinal tract.

${ }^{1}$ Values were calculated as internal organ weight/EBW. 
that of ewes during late fattening period (average age was 6 months). However, in present study, the discrepancy in $\mathrm{NE}_{\mathrm{m}}$ between early and late fattening period was $10.01 \mathrm{~kJ}$ per unit $\mathrm{SBW}^{0.75} / \mathrm{d}$. These data indicated that the adjustment of $\mathrm{NE}_{\mathrm{m}}$ for ages (4 vs 6 months) recommended by CSIRO was evidently less than that achieved in our study (1.28 vs 10.01 $\mathrm{kJ}$ per kilogram of $\mathrm{SBW}^{0.75} / \mathrm{d}$ ). The possible explanation for this discrepancy might be associated with the scope of application for the empirical formula, and the CSIRO recommended equation seemed more suitable to address the effect of age on $\mathrm{NE}_{\mathrm{m}}$ for the lambs with different ages at the annual interval, however, the discrepancy in ages was approximately 3 months in present study. This age difference was so small that CSIRO recommended adjustment of energy requirement for maintenance for age could not reflect the real difference in $\mathrm{NE}_{\mathrm{m}}$ between animals with different ages in the present study. In addition, we were obliged to concede that the seasonal factor might result in an inevitable change in appetite (Suttie and Webster, 1995; Tyler et al., 1999; Rhind et al., 2002), as Exp. 1 and Exp. 2 were launched in winter and summer, for younger and older ewes, respectively. Most consistent findings reported lower $\mathrm{NE}_{\mathrm{m}}$ accompanied with a decrease in level of intake in summer, and this might be a potential factor that contributed to the amplification of discrepancy in $\mathrm{NE}_{\mathrm{m}}$ with different ages.

The mean $\mathrm{ME}_{\mathrm{m}}$ value estimated for ewes during early and late fattening periods (401.99 and $371.23 \mathrm{~kJ} / \mathrm{kg}^{0.75}$ of $\mathrm{SBW} / \mathrm{d})$ were both less than that of Boer crossbred kids (430.75 kJ/kg ${ }^{0.75}$ of SBW/d; Fernandes et al., 2007) and indigenous Granadina goats $\left(570.0 \mathrm{~kJ} / \mathrm{kg}^{0.75}\right.$ of $\mathrm{SBW} / \mathrm{d}$; Prieto et al., 1990), which is in agreement with the observation of a lower fasting metabolism in sheep compared with goats (Cannas et al., 2004). Expressed as per unit of $\mathrm{BW}$, average $\mathrm{ME}_{\mathrm{m}}$ value $\left(386.61 \mathrm{~kJ} / \mathrm{kg}^{0.75}\right.$ of $\mathrm{BW} / \mathrm{d}$ ) of Dorper and $\mathrm{Hu}$ crossbred ewes during early and late fattening periods was greater than Baluchi ram lambs (342 $\mathrm{kJ} / \mathrm{kg}^{0.75}$ of BW/d; Kamalzadeh and Shabani, 2007) and less than British rams $\left(460 \mathrm{~kJ} / \mathrm{kg}^{0.75}\right.$ of $\mathrm{BW} / \mathrm{d}$; Dawson and Steen, 1998). As the comparisons above-mentioned were carried out between the previous reports for male lambs and results of female lambs in present study, these discrepancies in $\mathrm{ME}_{\mathrm{m}}$ may partly be associated with gender, aside from genotypes and diet factors. The slight decrease of $\mathrm{ME}_{\mathrm{m}}$ obtained in our study indicated that younger ewes with lower $\mathrm{BW}$ tended to have greater $\mathrm{ME}_{\mathrm{m}}$. As our results show, the $\mathrm{k}_{\mathrm{m}}$ values reported in the present study were 0.65 and 0.68 , for early and late fattening periods respectively. Whereas, NRC (2007) recommended a constant (0.644) value for sheep with different ages. These findings indicated that the divergence in effect of age on $\mathrm{ME}_{\mathrm{m}}$ between the NRC recommendation and present study, might attributed to variation in $\mathrm{k}_{\mathrm{m}}$ between ewes with different ages. When calculated as the equation described by AFRC (1993): $\mathrm{k}_{\mathrm{m}}=$ $0.503+0.35 \times \mathrm{ME} / \mathrm{GE}$, where $\mathrm{ME} / \mathrm{GE}$ values in the present study were 0.53 and 0.49 , for ewes during early and later fattening period respectively. The predicted values of $\mathrm{k}_{\mathrm{m}}$ would be 0.70 and 0.69 , which are approximately $6 \%$ and $1 \%$ greater than corresponding values in current study, respectively. These finding indicated that adoption of $\mathrm{k}_{\mathrm{m}}$ value of $A F R C$ would underestimate the $\mathrm{ME}_{\mathrm{m}}$ requirement for Dorper and $\mathrm{Hu}$ crossbred ewes, which is in disagreement with the study in Dorper crossbred ram lambs (Deng et al., 2012). We speculate that the explanation for this may partly be associated with gender.

The slightly greater value of $k_{g}$ for ewes in late fattening period (0.41) compared with the corresponding value for ewes in early fattening period (0.42), indicated that younger animals have a higher efficiency of ME utilization for growth. As proposed by NRC (2007), the array of nutrients absorbed, as affected by the nature of the diet, can impact the composition of tissue gain independent of the effect of diets on ADG. Because of the appreciable influence of diet characteristics on $k_{g}$, diet metabolizability has a larger effect on growth rate than DMI (Cannas et al., 2004). The method to estimate the $k_{g}$ for growing sheep described by (NRC, $2007)$ is given as; $k_{g}=\left([1.42 \times \mathrm{MEC}]-\left[0.174 \times \mathrm{MEC}^{2}\right]+\right.$ $\left.\left[0.0122 \times \mathrm{MEC}^{3}\right]-1.65\right) / \mathrm{MEC}$, where $\mathrm{MEC}$ is the $\mathrm{ME}$ concentration of the diets. For Dorper and $\mathrm{Hu}$ crossbred ewes from 20 to $35 \mathrm{~kg}$ of $\mathrm{BW}$, using an average value of MEC (2.76 Mcal/kg of DM) obtained from digestible trial during early fattening period, the NRC predicted value of $k_{g}$ would be 0.44 , which was approximately $5 \%$ greater than that of our value of 0.42 . For Dorper and Hu crossbred ewes ranging from 35 to $50 \mathrm{~kg}$ of $\mathrm{BW}$, using average value of MEC (2.66 Mcal/kg of DM) obtained from digestible trial during late fattening period, the estimated value of $k_{g}$ would be 0.42 ; which is approximately $3 \%$ greater of our value of 0.41 in present study. Results of present study suggest that recommendations proposed by NRC would underestimate the $k_{g}$ of both younger and elder ewes in our study. Therefore, adoption of the $k_{g}$ of NRC (2007) would overestimate the $\mathrm{ME}_{\mathrm{g}}$ for Dorper and $\mathrm{Hu}$ crossbred ewes.

Animal body energy content is mainly reflected by the whole body proportion of body fat and protein (Garrett, 1980). As shown in Table 5, the whole body proportion of protein decreased as EBW increased (slope of regression equations are 0.86 and 0.74 for early and late fattening periods, respectively), whereas whole body fat proportion increased with an increasing EBW (slope of regression equations are 1.56 and 1.84 for early and late fattening periods, respectively), hence, the body energy content should increase with stage of maturity. This finding was consistent with our results represented in Figure 2B. The discrepancy in stage maturity between ewes during early and late fattening period was always represented by the 
difference in body composition (ie. proportion of body protein, water, fat, and illustrated in Table 5). Take body fat proportion relative to EBW as an example, the whole body fat proportion of ewes during early fattening period with a $\mathrm{BW}$ ranging from 20 to $35 \mathrm{~kg} \mathrm{BW}$ was scaled from 127.14 to $174.12 \mathrm{~g} / \mathrm{kg}$ of EBW, however, the corresponding values of ewes in late fattening period were scaled from170.96 to $230.52 \mathrm{~g} / \mathrm{kg}$ of EBW. In addition, our data indicated that ewes with different ages presented a significant divergence in body composition accreted rate at the same level of BW gain, increasing of fat accreted, and decreasing of protein accreted with age increased. This was because of the relative higher concentration of water, and lower absolute value of calories in protein tissues compared with adipose tissues, on the mass or ADG basis the gain of protein is more efficient (NRC, 2007). Hence, $\mathrm{NE}_{\mathrm{g}}$ increased as the stage of maturity increases. These findings are similar to our results, the $\mathrm{NE}_{\mathrm{g}}$ values obtained for ewes from 20 to 35 $\mathrm{kg}$ of BW were significantly less than that of ewes from 35 to $50 \mathrm{~kg}$ of $\mathrm{BW}$ at the same level of ADG. For example, $\mathrm{NE}_{\mathrm{g}}$ values of ewes at $\mathrm{ADG}$ of $300 \mathrm{~g}$ ranged from 3.64 to 4.46 $\mathrm{MJ} / \mathrm{d}$, however, the $\mathrm{NE}_{\mathrm{g}}$ values of ewes from 35 to $50 \mathrm{~kg}$ of $\mathrm{BW}$ at $\mathrm{ADG}$ of $300 \mathrm{~g}$ ranged from 4.50 and $5.47 \mathrm{MJ} / \mathrm{d}$. In conclusion, we suggest that the divergence of $\mathrm{NE}_{\mathrm{g}}$ between early and late fattening periods might be attributed mainly to variation in growth rates, body composition, and stage of maturity. In comparison with data previously published, our estimated $\mathrm{NE}_{\mathrm{g}}$ values of Dorper and $\mathrm{Hu}$ crossbred with 35 $\mathrm{kg}$ of SBW at $300 \mathrm{~g}$ of ADG (4.55 MJ/d) is $8 \%$ less than value reported for Dorper and thin-tailed Han ewe lambs (4.92 MJ/d; Xu, 2012), whereas $35 \%$ greater than value reported for Dorper and thin-tailed Han ram lambs (3.37 MJ/d; Deng et al., 2012). Additionally, compared with body composition of Dorper and thin-tailed Han crossbred female lambs with $20 \mathrm{~kg}$ of SBW reported by Xu (2012), our ewes had a relative lower whole body fat proportion (125.74 vs $133.67 \mathrm{~g} / \mathrm{kg}$ of EBW), but relatively greater whole body protein proportion (214.68 vs $184.26 \mathrm{~g} / \mathrm{kg}$ of EBW), indicating that there exists a divergence in stage of maturity at the same BW between different genotypes, which resulted in the difference of energy requirements for growth. For ewes of $20 \mathrm{~kg} \mathrm{BW}, \mathrm{NE}_{\mathrm{g}}$ values recommended by NRC (2007) for early and late maturating growing rams at ADG of $300 \mathrm{~g}$ were 5.73 and $2.63 \mathrm{MJ} / \mathrm{d}$, which are significant greater and less than our values of $3.75 \mathrm{MJ} / \mathrm{d}$, respectively. In conclusion, we suggested that $\mathrm{NE}_{\mathrm{g}}$ values of Dorper and $\mathrm{Hu}$ crossbred ewes ranged between the NRC recommended results of $\mathrm{NE}_{\mathrm{g}}$ for early and later maturating growing sheep.

\section{CONCLUSION}

Comparing the nutrient requirements of ewes between early and late fattening period, $\mathrm{NE}_{\mathrm{g}}, \mathrm{ME}_{\mathrm{g}}$, and $\mathrm{k}_{\mathrm{m}}$ increased while $\mathrm{NE}_{\mathrm{m}}, \mathrm{ME}_{\mathrm{m}}$, and $k_{g}$ declined as age increased. Values of energy requirements for growth $\left(\mathrm{NE}_{\mathrm{g}}\right.$ and $\left.\mathrm{ME}_{\mathrm{g}}\right)$ ranged between the NRC (2007) recommendation for early and later maturating growing sheep.

\section{ACKNOWLEDGMENTS}

This work was supported by the China Agriculture Research System (No.CARS-39) and Special Fund for Agro-scientific Research in the Public Interest (No. 201303144 and 201303143), administrated by Department of Agriculture, China.

\section{REFERENCES}

AFRC. 1993. Energy and Protein Requirements of Ruminants: An Advisory Manual Prepared by the AFRC Technical Committee on Responses to Nutrients. CAB International, Wallingford, UK.

AOAC. 1990. Official Methods of Analysis. Association of Official Analytical Chemists Inc.Washington, DC, USA.

ARC. 1980. The Nutrient Requirements of Ruminant Livestock. Commonwealth Agricultural Bureaux, Slough, UK.

Blaxter, K. L. and J. L. Clapperton. 1965. Prediction of the amount of methane produced by ruminants. Br. J. Nutr. 19: 511-522.

Cannas, A., L. O. Tedeschi, D. G. Fox, A. N. Pell, and P. J. Van Soest. 2004. A mechanistic model for predicting the nutrient requirements and feed biological values for sheep. J. Anim. Sci. 82:149-169.

CSIRO. 2007. Nutrient Requirements of Domesticated Ruminants. Commonwealth Scientific and Industrial Research Organization Publishing; Melbourne, Vic, Australia.

Dawson, L. E. R. and R. W. J. Steen. 1998. Estimation of maintenance energy requirements of beef cattle and sheep. J. Agric. Sci. 131: 477-485.

Deng, K. D., Q. Y. Diao, C. G. Jiang, Y. Tu, N. F. Zhang, J. Liu, T. Ma, Y. G. Zhao, and G. S. Xu. 2012. Energy requirements for maintenance and growth of Dorper crossbred ram lambs. Livest. Sci. 150:102-110.

Fernandes, M. H. M. R., K. T. Resende, L. O. Tedeschi, J. S. Fernandes, H. M. Silva, G. E. Carstens, T. T. Berchielli, I. A. M. A. Teixeira, and L. Akinaga. 2007. Energy and protein requirements for maintenance and growth of Boer crossbred kids. J. Anim. Sci. 85:1014-1023.

Freetly, H. C., J. A. Nienaber, and T. M. Brown-Brandl. 2003. Relationship between aging and nutritionally controlled growth rate on heat production of heifers. J. Anim. Sci. 81: 1847-1852.

Galvani, D. B., C. C. Pires, G. V. Kozloski, and T. P. Wommer. 2008. Energy requirements of Texel crossbred lambs. J. Anim. Sci. 86:3480-3490.

Garrett, W. 1980. Factors influencing energetic efficiency of beef production. J. Anim. Sci. 51:1434-1440.

Ji, S. K., G. S. Xu, C. G. Jiang, K. D. Deng, Y. Tu, N. F. Zhang, T. Ma, C. Lou, and Q. Y. Diao. 2013. Net phosphorus requirements of Dorperx Thin-tailed han crossbred ram lambs. Asian Australas. J. Anim. Sci. 26:1282-1288. 
Kamalzadeh, A. and A. Shabani. 2007. Maintenance and growth requirements for energy and nitrogen of Baluchi sheep. Int. J. Agric. Biol. (Pakistan).

NRC. 2007. Nutrient requirements of small ruminants: Sheep, goats, cervids, and new world camelids. Natl. Acad. Press Washington, DC, USA.

Pires, C. C., L. F. D. Silva, and L. M. Bonnecarrère Sanchez. 2000. Corporal composition and nutritional requirements for energy and protein of growing lambs. Rev. Bras. Zootec. 29:853-860.

Prieto, C., J. F. Aguilera, L. Lara, and J. Fonollá. 1990. Protein and energy requirements for maintenance of indigenous Granadina goats. Br. J. Nutr. 63:155-163.

Rhind, S., Z. Archer, and C. Adam. 2002. Seasonality of food intake in ruminants: Recent developments in understanding. Nutr. Res. 15:43-65.

Suttie, J. M., and J. R. Webster. 1995. Extreme seasonal growth in arctic deer: comparisons and control mechanisms. Am. Zool. $35: 215-221$.
Seve, B. and A. A. Ponter. 1997. Nutrient-hormone signals regulating muscle protein turnover in pigs. Proc. Nutr. Soc. 56: 565-580.

Silva, A. M. A., A. G. da Silva Sobrinho, I. A. C. M. Trindade, K. T. Resende, and O. A. Bakke. 2003. Net requirements of protein and energy for maintenance of wool and hair lambs in a tropical region. Small Rumin. Res. 49:165-171.

Tyler, N. J. C., P. Fauchald, O. Johansen, and H. R. Christiansen. 1999. Seasonal inappetence and weight loss in female reindeer in winter. Ecol. Bull. 47:105-116.

Van Soest, P. J., J. B. Robertson, and B. A. Lewis. 1991. Methods for dietary fiber, neutral detergent fiber, and nonstarch polysaccharides in relation to animal nutrition. J. Dairy Sci. 74:3583-3597.

Xu, G. S. 2012. Study on Energy and Protein Requirements of 20 to $35 \mathrm{~kg}$ Dorper and thin-tailed Han Crossbred Lambs. PhD Thesis. Chinese Academy of Agricultural Sciences, Beijing, China (In Chinese). 